\title{
Mucuna pruriens Seed Extract Promotes Neurite Outgrowth via Ten-4 Dependent and Independent Mechanisms in Neuro2a Cells
}

(Ekstrak Biji Mucuna pruriens Menggalakkan Pertumbuhan Neurit melalui Mekanisme

Pergantungan Ten-4 dan Mekanisme Bebas Ten-4 dalam Sel Neuro2a)

\author{
Sutin WANSAWAT, MANi IYER PRASANTH, Ciro ISIDORO \& TEWIN TENCOMNAO*
}

\begin{abstract}
Neurological diseases are one of the serious health hazards faced by mankind for decades. Neurite outgrowth is a key factor responsible for proper neuronal development. Any misplacement in the process could lead to neurological diseases like Alzheimer's and Parkinson's. Treatment with the available synthetic drugs imparts many difficulties to the patients due to the side effects. Compounds from natural sources can be considered as an effective replacement for this. Mucuna pruriens, used in traditional ayurvedic medicine, contains L-3,4-dihydroxy phenylalanine (L-DOPA) in its seeds, which possesses medicinal effects against neurological diseases. In this regard, seed extracts of M. pruriens originated from Thailand and India, were analyzed for their neuroprotective effects in Neuro2a cells. Hexane, ethyl acetate and ethanol extracts were found to be non-toxic to the viability of the cells. Ethanol extracts of M. pruriens of Thai origin (MTE), hexane extracts of M. pruriens of Indian origin (MIH) and ethyl acetate extracts of M. pruriens of Indian origin (MIEA) were able to induce neurite outgrowth in Neuro2a cells. Interestingly, both MTE and MIH induced neurite outgrowth dependent on Teneurin-4 (Ten-4) transmembrane protein whereas MIEA did the same independent of Ten-4, which was confirmed by real time PCR and gene silencing approach. The present study suggested that M. pruriens can be used as a potential drug in the treatment of neurological diseases as it can induce neurite outgrowth by multiple mechanisms, which will be of great use in the field of medicine.
\end{abstract}

Keywords: Neurite outgrowth; neuro2a cells; neurodegenerative diseases; Ten-4

ABSTRAK

Penyakit neurologi adalah salah satu penyakit serius yang dihadapi oleh manusia selama beberapa dekad. Pertumbuhan neurit merupakan faktor utama yang bertanggungjawab untuk perkembangan neuron yang betul. Sebarang kesilapan dalam proses tersebut boleh membawa kepada penyakit neurologi seperti Alzheimer dan Parkinson. Rawatan dengan ubatan sintetik sedia ada memberikan banyak kesulitan kepada pesakit akibat kesan sampingan. Sebatian daripada sumber semula jadi boleh dianggap sebagai pengganti berkesan untuk ini. Biji Mucuna pruriens yang digunakan dalam perubatan tradisi ayurveda, mengandungi L-3,4-dihidroksi fenilalanina (L-DOPA) yang mempunyai kesan perubatan terhadap penyakit neurologi. Dalam hal ini, ekstrak biji benih daripada M. pruriens yang berasal dari Thailand dan India, dianalisis untuk kesan neuroperlindungan di dalam sel Neuro2a. Ekstrak heksana, etil asetat dan etanol didapati tidak toksik kepada kebolehidupan sel-sel. Ekstrak etanol M. pruriens Thailand (MTE), ekstrak heksana dari M. pruriens India (MIH) dan ekstrak etil asetat dari M. pruriens India (MIEA) dapat mendorong pertumbuhan neurit dalam sel Neuro2a. Kedua-dua MTE dan MIH yang menggalakkan pertumbuhan neurit bergantung kepada protein transmembran Teneurin-4 (Ten-4) manakala MIEA tidak bergantung pada Ten-4. Ini telah disahkan menggunakan PCR dan pendekatan penyenyapan gen. Kajian ini menunjukkan bahawa M. pruriens boleh digunakan sebagai ubat berpotensi dalam merawat penyakit neurologi kerana ia dapat mendorong pertumbuhan neurit melalui pelbagai mekanisme, yang dapat digunakan dengan baik dalam bidang perubatan.

Kata kunci: Penyakit 'neurodegenerative'; pertumbuhan neurit; sel Neuro2a; Ten-4

\section{INTRODUCTION}

Advancements in the field of medicine have increased the life expectancy of people in developed and developing countries. However, this leads to an increase of old age people who are prone to age related diseases. According to World Health Organization, there will be a constant increase of ratio of old age population that they may exceed in number when compared to children below 5 years of age by 2020. In this regard, there is a growing need to find efficient strategies to improve the healthcare aspects of people. Neurological disorders are supposed to be the major problem faced by old age people.

One of the important aspects of neuronal development is neurite outgrowth process, which is necessary for synaptic plasticity and neuronal regeneration after injury (Phan et al. 2015, 2013). Any abnormalities in neurite 
formation will lead to neurodegenerative diseases that are multifactorial and can cause debilitating disorders in the nervous system such as Alzheimer's, Parkinson's and Huntington's diseases. Under normal conditions, the neurotrophic factors such as Nerve growth factors (NGF) and Brain-derived neurotrophic factors (BDNF) are endogenous substances which are known to increase synaptic efficiency, neuronal survival as well as neurite formation.

However, the increased molecular weight of NGF can be a hindrance in crossing the blood-brain barrier inside the host (Phan et al. 2015). In this regard, alternative sources as to be identified to induce neurite formation. Bioactives from plant sources have been widely used recently in this field because of the numerous advantages they have when compared to the other sources. Many plants like Panax ginseng, Curcuma longa, Camellia sinensis, Withania somnifera, Citrus depressa, Sargassum macrocarpum, Tripterygium wilfordii and Scutellaria baicalensis are some of the plant species which have been observed to have neurite outgrowth activity (More et al. 2012).

Mucuna pruriens is found widely in Asia, Africa, America and the Pacific Islands. It is commonly known as 'Velvet bean' which can cause itching and irritation when contacted in skin because of the presence of mucunain in the pod (Lampariello et al. 2012). However, the seeds of the plant were observed to have medicinal value which is routinely used in Ayurveda, since it contains L-3,4-dihydroxy phenylalanine, which is otherwise known as levodopa or L-DOPA, the precursor of dopamine neurotransmitter. This is very vital in treating Parkinson's disease (Pulikkalpura et al. 2015; Raina \& Khatri 2011). Additionally, the plant is also known to elicit protective effect against different microbes, diabetes, snake poisoning and skin allergens. A recent study showed that M. pruriens have antioxidant activity due to the presence of different phytochemicals like polyphenols, phenolic and flavonoid compounds (Riaz et al. 2017), which might scavenge the free radicals that induce neurodegenerative diseases. However, the role of $M$. pruriens in neurite outgrowth as not been completely elucidated.

The use of synthetic drugs may have many side effects, which could also become ineffective in the longer run. Active compounds from plants or other natural sources becomes critical in this juncture since it can overcome the drawbacks of synthetic drugs and are comparatively safer. Claulansine F isolated from the stem of Clausena lansium and artemisinin from Artemisia annua were observed to promote neuritogenesis via activation the ERK signaling and p38 MAPK pathway in PC12 cells (Ma et al. 2013; Sarina et al. 2013). Uridine extracted from Pleurotus giganteus was observed to increase the phosporylation of MEK/ERK, PI3K/Akt/mTOR, CREB and GAP43, which can promote neurite growth in Neuro2a cells (Pan et al. 2015). Similarly, Senegenin extracted from Polygala tenuifolia were observed to have neurite outgrowth ability, which is mediated by MAP2 and GAP-43 expression in PC12 cells (Jesky \& Chen 2016).
Teneurin-4 (Ten-4) is a type II transmembrane protein which is highly expressed in central nervous system. It plays a major role in regulating oligodendrocyte differentiation, myelination, filopodia-like protrusion as well as neurite formation (Suzuki et al. 2012). Ten-4 expression was found to be upregulated during neurite outgrowth in Neuro-2a cell lines. Neuro2a cells derived from C1300 mouse neuroblastoma were routinely used to study the effects of different chemical and natural compounds on neuronal differentiation and proliferation, neuronal toxicity and neurite outgrowth (Salto et al. 2015). Additionally, expression of Ten-4 is important for filopodia-like protrusions and the length of individual neuritis. Interestingly, the expression of Ten- 4 was found to be higher in Neuro2a cells when compared to PC12 (Suzuki et al. 2014). However, the mode of action of Ten-4 in Neuro2a cells supplemented with natural herbs has not been studied.

In the present study, we have tried to understand the effect of $M$. pruriens seed extracts originated from Thailand and India in determining neurite outgrowth in Neuro2a cells. Additionally, we have tried to determine the mode of action of Ten-4 in this process by gene silencing method. This study could pave way in determining natural compounds from plant origin in developing novel drugs which could prevent as well as treat neurodegenerative diseases.

\section{MATERIALS AND METHODS}

\section{CELLS AND REAGENTS USED}

The mouse neurobalastoma cells, Neuro2a cell lines, were provided by Prof. Dr. Ciro Isidoro from Università Del Piemonte Orientale, Italy. These cells were cultured in Dulbecco's Modified Eagle's Medium (DMEM) supplemented with $10 \%$ fetal bovine serum (FBS), HAMF12, MEMNESS and $1 \%$ penicillin/streptomycin as antibiotics. The cells were constantly maintained at $37^{\circ} \mathrm{C}$ along with $5 \% \mathrm{CO}_{2}$ in a humidified incubator.

DMEM, FBS, HAMF12 and MEMNESS were purchased from Sigma-Aldrich (Sigma-Chemical Co., USA). 1\% penicillin/streptomycin antibiotics were purchased from Thermo Scientific (Hudson, NH, USA). Ethanol, Ethyl acetate and Hexane were purchased from Merck (Germany).

\section{PREPARATION OF HERBAL EXTRACTS}

Seed of Thai and India M.pruriens were derived from the Princess Maha Chakri Sirindhorn Herbal Garden (Rayong province, Thailand). They were authenticated at the Professor Kasin Suvatabhandhu Herbarium, Department of Botany, Faculty of Science, Chulalongkorn University, Thailand. The voucher specimens of these herbal plants are 015786 (BCU) and 015855 (BCU). The herbal plant powders $(40 \mathrm{~g})$ were extracted using the solvents hexane, ethyl acetate and ethanol $(400 \mathrm{~mL})$ using Soxhlet 
apparatus and were dried by using rotatory evaporation. The dried crude herbal plant extracts were dissolved in dimethyl sulfoxide (DMSO) and then filtered using 0.2 um pore size filter paper to make stock solutions (100 $\mathrm{mg} / \mathrm{mL}$ ). These crude herbal plant extracts were stored at $-20^{\circ} \mathrm{C}$ for further use.

\section{CELL VIABILITY ASSAY}

MTT assay was performed to determine the cell viability. Neuro2a cells were seeded at a density of $5 \times 10^{3}$ cells in each well of a 96-well plate. After incubation for $24 \mathrm{~h}$, different concentrations of herbal plant extracts (0-100 $\mu \mathrm{g} / \mathrm{mL}$ ) added to each well of 96-well plates and then incubated for $48 \mathrm{~h}$ at $37^{\circ} \mathrm{C}$ with $5 \% \mathrm{CO}_{2}$ in a humidified incubator. $20 \mu \mathrm{l}$ of MTT reagent $(5 \mathrm{mg} / \mathrm{mL})$ was added to each well for $3 \mathrm{~h}$ and then the purple formazan was dissolved in DMSO. The absorbance was measured at 550 $\mathrm{nm}$ using a microplate reader (Biotek, USA).

\section{NEURITE OUTGROWTH ASSAY (NEURITE LENGTH AND NEURITE-BEARING CELL)}

Neuro2a cells were seeded in a petri dish at a density of $1.5 \times 10^{4}$ cells per petri dish supplemented with $10 \%$ FBS containing DMEM medium ( $2 \mathrm{~mL}$ per petri dish) and incubated for $24 \mathrm{~h}$. Hexane, ethyl acetate and ethanol extracts of $M$. pruriens seeds originated from Thailand (now on will be mentioned as MTH, MTEA and MTE, respectively) and India (now on will be mentioned as MIH, MIEA and MIE, respectively) were dissolved in $1 \%$ FBS containing DMEM medium. To induce cell differentiation, the $10 \%$ FBS containing DMEM medium was carefully replaced with $1 \%$ FBS containing DMEM medium before treatment with the seed extracts at $12.5 \mu \mathrm{g} / \mathrm{mL}$. Cells in $10 \%$ FBS containing DMEM medium alone served as negative control whereas cells in 1\% FBS containing DMEM medium alone served as positive control. The cells with the extracts along with control were incubated for $48 \mathrm{~h}$ at $37^{\circ} \mathrm{C}$ and $5 \% \mathrm{CO}_{2}$ in humidified incubator to observe neuritogenic activity. The random fields (100-200 cells) were examined in each dish by using a phase contrast microscope at $10 \times$ magnifications equipped with Canon EOS 50D. Neurite-bearing cells and neurite length were measured in randomly chosen fields by using ImageJ software.

\section{RNA ISOLATION AND QUANTITATIVE REAL-TIME PCR}

Real Time PCR was performed to determine the mRNA expression of Ten-4 in Neuro2a cells. Total RNA samples were isolated from Neuro2a cells at a density of $9 \times$ $10^{4}$ cells per dish using TRIzol (Ambion, Austin, TX, USA) method and quantified by using Nano-drop at an absorbance of $260 \mathrm{~nm}$. The RNA purity was determined determining the A260/A280 ratio. One microgram of total RNA samples were reverse transcribed to cDNA by reverse transcriptase enzyme (Thermo Scientific, Hudson, NH, USA) and cDNA of samples were used as templates for quantitative real-time PCR, which was performed using SYBR Green of the Accupower 2× Greenstar qPCR Master Mix by using Exicycler ${ }^{\mathrm{TM}}$ version 3.0 (Bioneer Co.). The condition consists of Pre- Denaturation: $95^{\circ} \mathrm{C}$ for $10 \mathrm{~min}$, Denaturation: $95^{\circ} \mathrm{C}$ for $15 \mathrm{~s}$, Annealing ( $45 \mathrm{cycle}$ ): $62^{\circ} \mathrm{C}$ for $15 \mathrm{~s}$, Extension: $72^{\circ} \mathrm{C}$ for $30 \mathrm{~s}$. The gene-specific primers used are: Ten- 4 : 5'-GTGGACAAGTTTGGGCTCATTTA3' (Forward), 5'GGGTTGATGGCTAAGTCTGTGG-3' (Reverse) and $\beta$-actin: 5'-GTTGACATCCGTAAAGACC-3' (Forward), 5'-TGGAAGGTGGACAGTGAG-3' (Reverse). The fold change of the target genes were analyzed by using the $2^{-\Delta \Delta \mathrm{Ct}}$ method. The CT value of the target gene Ten- 4 was normalized against $\beta$-actin mRNA standards.

\section{KNOCKDOWN OF TEN-4}

To understand the role of Ten- 4 during treatment with herbal extracts, knockdown of Ten-4 was done in Neuro2a cells (Thermo Fisher Scientific). On-target plus nontargeting siRNA (Thermo Fisher Scientific) was used as control. The siRNA were transfected into Neuro2a cells using the FuGENE (Promega, Wisconsin, USA). The Knockdown efficiency was assessed by quantitative real-time PCR. All the cells were transfected using in neurite outgrowth and quantitative real-time PCR experiment.

\section{STATISTICAL ANALYSIS}

All the experiment data were expressed as mean \pm standard deviation (SD) from three independent experiments. Statistical differences between groups were determined by one-way analysis of variance (ANOVA) followed by LSD test using the SPSS Ver.22.0 (IBM SPSS Inc,Chicago,Illinosis). $p<0.05$ was considered to be significant.

\section{RESULTS AND DISCUSSION}

\section{SEED EXTRACTS DID NOT AFFECT THE VIABILITY OF NEURO2A CELLS}

Neuro2a cells were seeded in a 96 well plate for $24 \mathrm{~h}$, followed by treatment with MTH, MTEA, MTE, MIH, MIEA and MIE individually at different concentrations varying from $0-100 \mathrm{mg} / \mathrm{mL}$ for $48 \mathrm{~h}$. It was observed that all the concentrations tested in the different seed extracts were non-toxic, wherein minimum of $80 \%$ of cell viability was observed in all the plates (Figure 1).

Plants, herbs and other natural sources have been widely considered by researchers as an effective replacement for many diseases. As discussed earlier, $M$. pruriens containing L-DOPA can be used for treatment of Parkinson's disease which also has anti- inflamation, antibacterial, and antioxidant activity. However, it is essential to identify the optimum concentration of the plant extract which is non-toxic and also induce positive effect in the cells. The cell viability assay indicated that the seed extract taken from different solvents were non-toxic to Neuro2a cells (Figure 1). Additionally, $12.5 \mu \mathrm{g} / \mathrm{mL}$ was able to induce highest neurite outgrowth activity in Neuro2a cells 
A

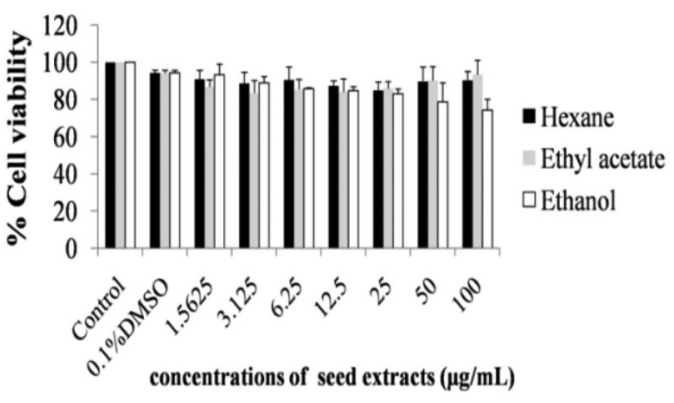

B

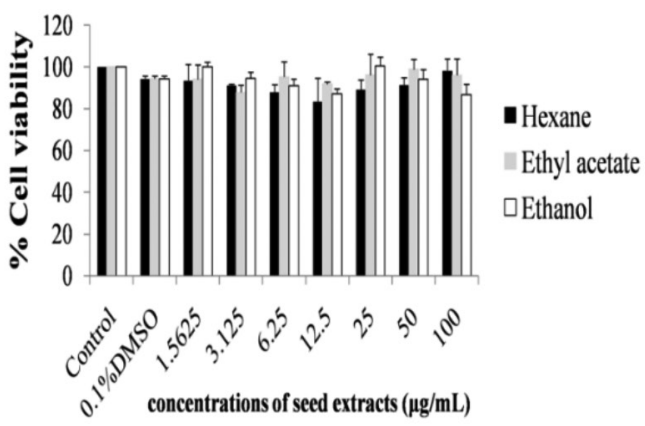

FIGURE 1. Effects of crude seed extracts of M. pruriens of (A) Thai origin and (B) Indian origin on the viability of Neuro2a cells. Different concentrations between $0-100 \mu \mathrm{g} / \mathrm{mL}$ were tested. Cells with no treatment and cells with $0.1 \%$ DMSO (solvent control) were considered as control. The data was represented as mean \pm SD

wherein higher concentrations were slightly toxic (Data not shown). This could be due to the lower concentration of FBS used in the analysis of neurite outgrowth when compared to analysis of cell viability (Wang et al. 2004).

\section{SELECTIVE EXTRACTS CAN ENHANCE NEURITE OUTGROWTH ACTIVITY}

Neuro2a cells treated with $12.5 \mu \mathrm{g} / \mathrm{mL}$ of the different seed extracts were analyzed for neurite outgrowth activity (Figure 2). It was observed that MIH (23.77 $\pm 1.6 \%)$, MIEA $(24.13 \pm 0.8 \%)$ and MTE $(24.84 \pm 1.9 \%)$ sowed significant increase $(p<0.001)$ in neurite outgrowth when compared to the positive control $(18.66 \pm 1.5 \%$ ) (Figure 2(A)). Even though the other seed extracts, MIE (20.92 $\pm 1.6 \%)$, MTH $(20.3 \pm 0.5 \%)$ and MTEA $(19.37 \pm 0.3 \%)$, were able to outgrow neurite than the positive control, it was not as significant as the other extracts (Figure 2(A)). Additionally, the average neurite length was also monitored wherein MIH $(17.19 \pm 2.3 \mu \mathrm{m}), \operatorname{MIEA}(20.29 \pm 4.5 \mu \mathrm{m})$ and MTE $(17.65$ $\pm 2.3 \mu \mathrm{m}$ ) were observed to have significantly longer neurites when compared to the positive control (11.68 \pm $1.3 \mu \mathrm{m})(p<0.05)$. Even though MIE $(12.47 \pm 3.1 \mu \mathrm{m})$ and MTH $(13.84 \pm 1.5 \mu \mathrm{m})$ were able to produce longer neurites than the positive control, it was not significant. On the other hand, MTEA $(10.2 \pm 1.6 \mu \mathrm{m})$ could not produce longer neurite than the control (Figure 2(B)). The cell morphology
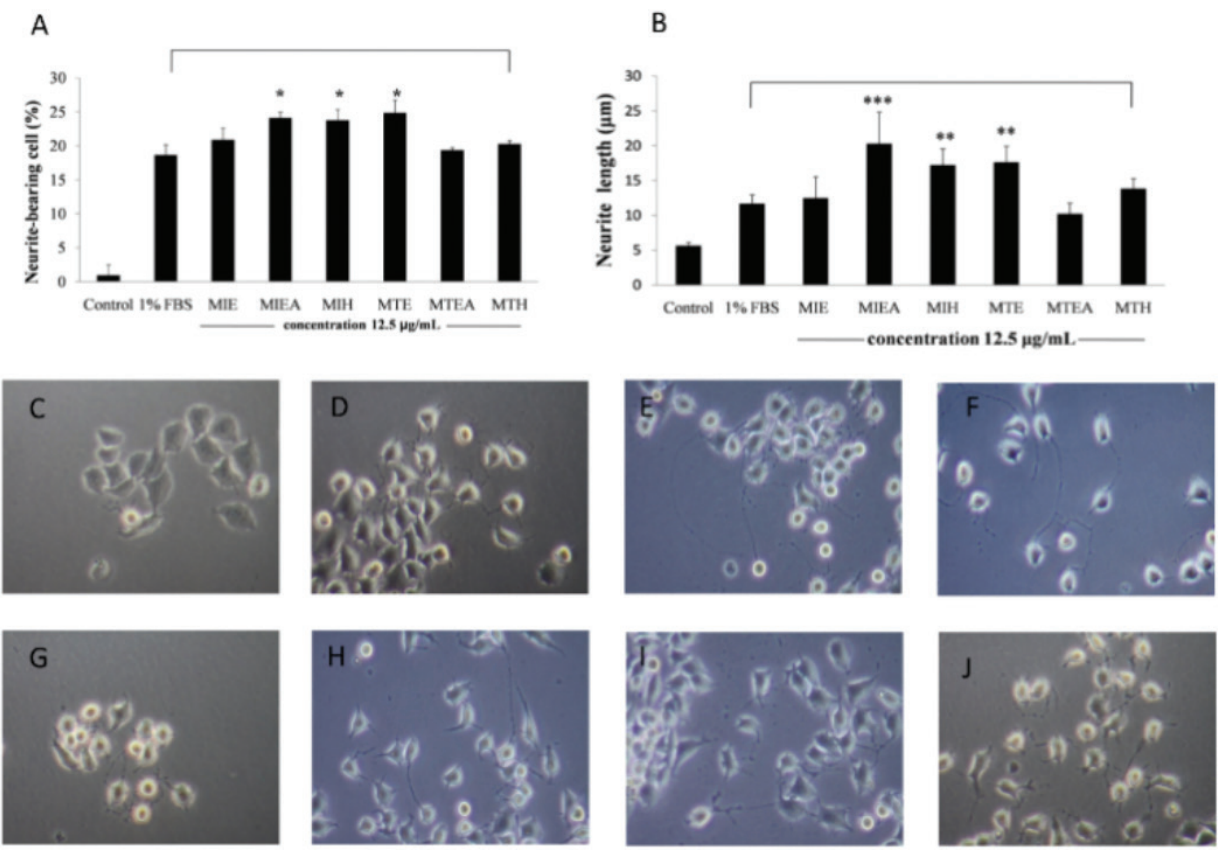

FIGURE 2. Effect of M. pruriens in inducing neurite outgrowth in Neuro2a cells. (A) Neurite bearing cells post treatment of plant extracts. (B) Neurite length of cells post treatment of plant extracts using ImageJ. The data was represented as mean \pm SD. $* p<0.05, * * p<0.01, * * * p<0.001$ versus positive control group. Phase contrast microscopic images of (C) 10\% FBS containing DMEM (control), (D) 1\% FBS containing DMEM (control), (E) MIH, (F) MIEA,

(G) MIE, (H) MTH, (I) MTEA and (J) MTE showing presence and length of neurite 
observed through phase contrast microscope also suggested the same (Figure 2(C)-2(J)).

Neurite outgrowth determines the normal development of the nervous system. However, it also plays a major role in treating neurodegenerative diseases by repairing the injured nerves (Brimson et al. 2018). Previous reports suggested the role of natural sources or chemical compounds extracted from it in enhancing the neurite outgrowth. Methyl-3,4-dihydroxybenzoate (MDHB) extracted from Kalimeris indica was observed to induce neurite outgrowth in cortical neurons (Zhang et al. 2015). Additionally, polyphenols from green tea, EGCG was observed to promote neurite outgrowth in PC12 cells (Gundimeda et al. 2010) whereas another phenolic compound, Cyanidin-3-Glucoside was observed to promote in Neuro2a (Chen et al. 2009).

Interestingly, the seed extracts of $M$. pruriens, especially MIH, MIEA and MTE were able to show significant neurite outgrowth when compared to the control (Figure 2 ). Even though the other extracts were also able to induce neurite outgrowth, it was not significant. This suggests that the different extracts were capable enough to induce neurite outgrowth, thereby aiding in the treatment of neurodegenerative diseases and protecting the nervous system. L-DOPA is the natural compound shown previously to induce neurite outgrowth (Mena et al. 1998). Mucuna pruriens seed extracts are known to contain a high concentration of L-DOPA. Therefore, L-DOPA in the Mucuna pruriens seed extracts might be the potential candidate promoting neurite outgrowth.

\section{SEED EXTRACTS CAN UPREGULATE THE EXPRESSION OF TEN-4}

The RNA isolated from Neuro2a cells treated with MIH, MIEA and MTE were converted to cDNA and analyzed for the expression of Ten-4. Significant upregulation was observed in MIH and MTE treated samples when compared to control (Figure 3).

Ten-4 is a transmembrane protein which plays key roles in neuronal development, oligodendrocyte differentiation and neurite outgrowth (Suzuki et al. 2014). Also, in the present study, Ten-4 was observed to be significantly upregulated in cells treated with MIH and MTE (Figure 3), suggesting the role of Ten-4 in neurite outgrowth. However, Ten-4 is not the sole player which can mediate neurite outgrowth. As discussed earlier, the ERK signaling and p38 MAPK pathway (Ma et al. 2013; Sarina et al. 2013), the MEK/ERK, PI3K/Akt/mTOR and CREB (Pan et al. 2015), the MAP2 and GAP-43 expression (Jesky $\&$ Chen 2016) can also aid in neurite outgrowth. In this regard, silencing of Ten-4 was performed to understand the possible role of it in neurite outgrowth during M.pruriens seed extract treatment.

\section{TEN-4 IS REQUIRED FOR THE SEED EXTRACTS TO INDUCE NEURITE GROWTH}

Further, to understand the role of Ten-4 in inducing neurite growth when treated with seed extracts, gene silencing was performed. Neuro2a cells were transfected with siTen-4 wherein siRNA-nontargeting (siRNA-scramble) served as control. Seed extracts were treated to these cells and analyzed for neurite growth along with quantitative PCR expression of Ten- 4 . The mRNA expression of Ten-4 in the silenced cells suggests that the gene was not active in the cells (Figure 4(A)). The cell morphology was observed through phase contrast microscope (Figure 4(B)-4(K)) which suggested significant decrease in neurite outgrowth and length in the silenced cells treated with MIH and MTE when compared to control (Figure 4(L)-4(M)). These data indicated that Ten-4 is required for MIH and MTE to induce neurite growth.

MIH and MTE along with MIEA were observed to induce neurite outgrowth (Figure 2). However, Ten-4 was observed to be upregulated only on MIH and MTE (Figure 3). Parallel to this, gene silencing of Ten-4 nullified the neurite outgrowth effect of MIH and MTE (Figure 4). Interestingly, MIEA was able to induce neurite outgrowth even in the absence of Ten-4 (Figure 4). This suggested that MIH and MTE induce neurite outgrowth which is dependent on Ten-4

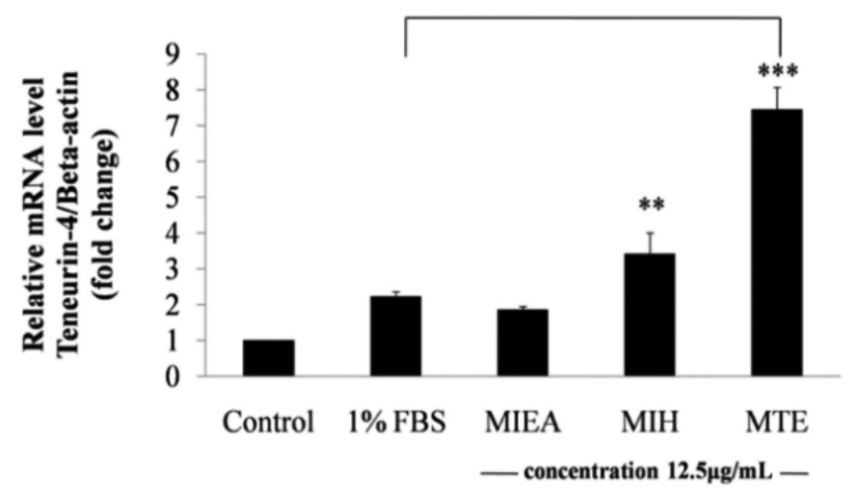

FIGURE 3. Relative mRNA expression of Ten-4 in Neuro2a cells treated with MIEA, MIH and MTE. Cells in 10\% FBS or 1\% FBS alone was considered as negative control and positive control, respectively. The data was represented as mean $\pm \mathrm{SD}$. $* * p<0.01$, $* * * p<0.001$ versus positive control group 

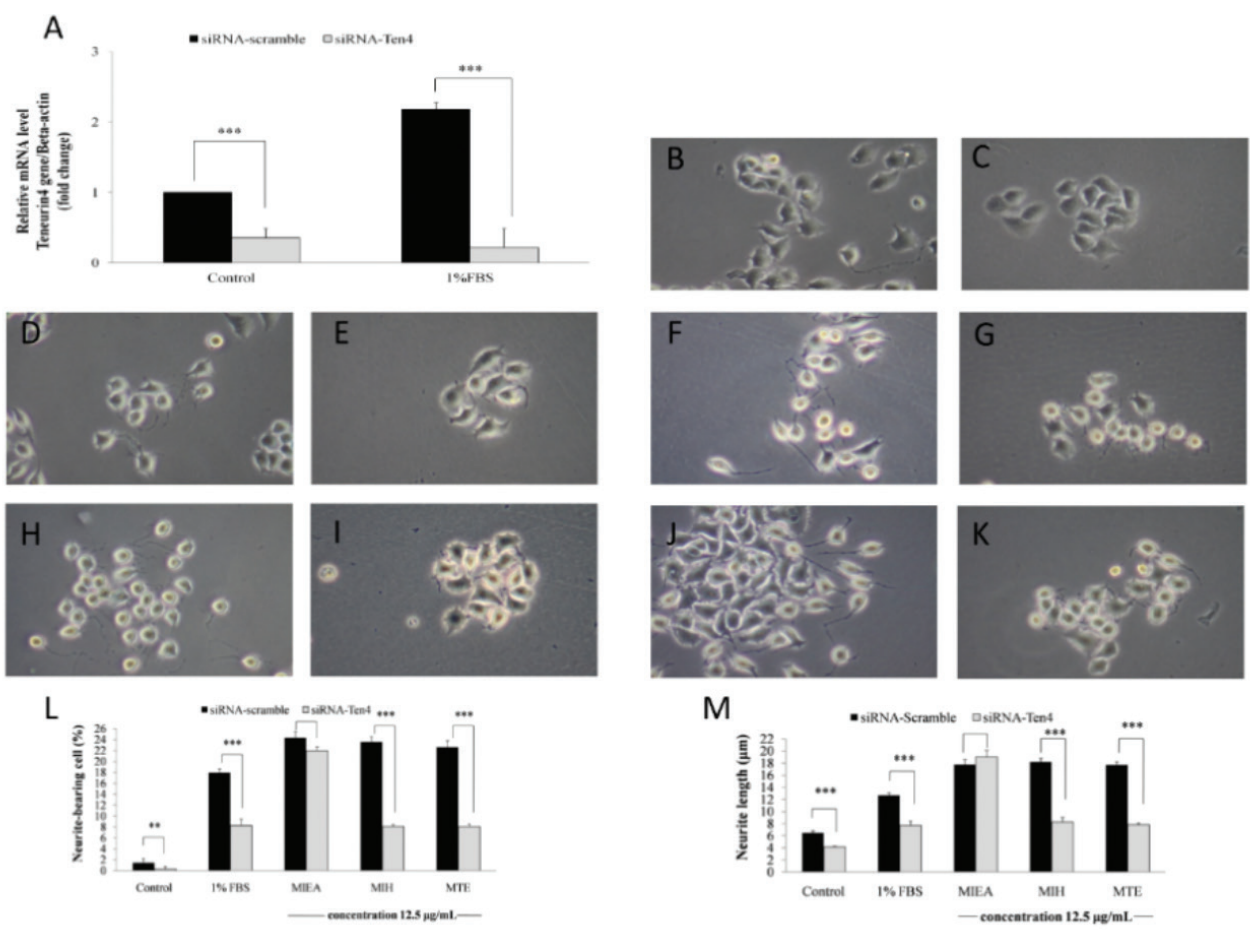

FIGURE 4. Role of Ten-4 in M. pruriens mediated neurite outgrowth analyzed by knockout of Ten-4. (A) Real time PCR expression of Ten-4 after transfection with siRNA-Ten-4 or siRNA-scramble. Cell morphology after transfection with siRNA-Ten-4 or siRNAscramble of (B) 10\% FBS siRNA-scramble, (C) 10\% FBS siRNA-Ten-4, (D) 1\% FBS siRNA-scramble, (E) 1\% FBS siRNA-Ten-4, (F) MIEA siRNA-scramble, (G) MIEA siRNA-Ten4, (H) MIH siRNA-scramble, (I) MIH siRNA-Ten-4, (J) MTE siRNA-scramble and (K) MTE siRNA-Ten-4. (L) Percentage of cells bearing neurites after treatment with M.pruriens seed extracts in transfected cells.

(M) Length of the neurites in transfected cells treated with M. pruriens seed extracts. The data was represented as mean \pm SD. $* * p<0.01, * * * p<0.001$ versus positive control group

whereas MIEA can induce the same independent of Ten-4. This could be a vital lead in the field of pharmacy since M. pruriens can induce neurite outgrowth via different mechanisms.

\section{CONCLUSION}

M. pruriens seed extracts from Thai and Indian origin were non-toxic to Neuro2a cell lines and were able to initiate neurite outgrowth. This was dependent (MIH and MTE) and independent (MIEA) of Ten-4, which suggests that $M$. pruriens can initiate neurite outgrowth mediated by different pathways. Studies using in vivo models in this aspect will lead to a potential drug candidate in treatment of neurological diseases which can target multiple pathways.

\section{ACKNOWLEDGEMENTS}

This study was financially supported by the 90th Anniversary Fund (Ratchadaphiseksomphot 19 Endowment Fund) of Chulalongkorn University (Grant no. GCUGR1125603066M). Mani Iyer Prasanth wishes to thank Rachadapisek Sompote Fund for Postdoctoral Fellowship, Chulalongkorn University, Thailand.

\section{REFERENCES}

Brimson, J.M., Safrany, S.T., Qassam, H. \& Tencomnao, T. 2018. Dipentylammonium binds to the sigma-1 receptor and protects against glutamate toxicity, attenuates dopamine toxicity and potentiates neurite outgrowth in various cultured cell lines. Neurotox. Res. 34(2): 263-272.

Chen, G., Bower, K.A., Xu, M., Ding, M., Shi, X., Ke, Z.J. \& Luo, J. 2009. Cyanidin-3-glucoside reverses ethanol-induced inhibition of neurite outgrowth: Role of glycogen synthase kinase 3 Beta. Neurotox. Res. 15(4): 321-331.

Gundimeda, U., McNeill, T.H., Schiffman, J.E., Hinton, D.R. \& Gopalakrishna, R. 2010. Green tea polyphenols potentiate the action of nerve growth factor to induce neuritogenesis: Possible role of reactive oxygen species. J. Neurosci. Res. 88(16): 3644-3655.

Jesky, R. \& Chen, H. 2016. The neuritogenic and neuroprotective potential of senegenin against $\mathrm{A} \beta$-induced neurotoxicity in PC 12 cells. BMC Complement. Altern. Med. 16: 26.

Lampariello, L.R., Cortelazzo, A., Guerranti, R., Sticozzi, C. \& Valacchi, G. 2012. The magic velvet bean of Mucuna pruriens. J. Tradit. Complement. Med. 2(4): 331-339.

Ma, Y.Z., Ning, N., He, W.B., Li, J.W., Hu, J.F., Chu, S.F. \& Chen, N.H. 2013. Claulansine F promotes neuritogenesis in PC12 cells via the ERK signaling pathway. Acta Pharmacol. Sin. 34(12): 1499-1507.

Mena, M.A., Davila, V., Bogaluvsky, J. \& Sulzer, D.A. 1998. Synergistic neurotrophic response to l-dihydroxyphenylalanine and nerve growth factor. Mol. Pharmacol. 54(4): 678-686. 
More, S.V., Koppula, S., Kim, I.S., Kumar, H., Kim, B.W. \& Choi, D.K. 2012. The role of bioactive compounds on the promotion of neurite outgrowth. Molecules 17(6): 6728-6753.

Phan, C.W., David, P., Naidu, M., Wong, K.H. \& Sabaratnam, V. 2013. Neurite outgrowth stimulatory effects of culinarymedicinal mushrooms and their toxicity assessment using differentiating Neuro-2a and embryonic fibroblast BALB/3T3. BMC Complement. Altern. Med. 13: 261.

Phan, C.W., David, P., Wong, K.H., Naidu, M. \& Sabaratnam, V. 2015. Uridine from Pleurotus giganteus and its neurite outgrowth stimulatory effects with underlying mechanism. PLOS ONE 10(11): e0143004.

Pulikkalpura, H., Kurup, R., Mathew, P.J. \& Baby, S. 2015. Levodopa in Mucuna pruriens and its degradation. Sci.Rep. 5: 11078

Raina, A.P. \& Khatri, R. 2011. Quantitative determination of L-DOPA in seeds of Mucuna pruriens germplasm by high performance thin layer chromatography. Indian J. Pharm. Sci.73(4): 459-462.

Riaz, M., Shahid, M., Jamil, A. \& Saqib, M. 2017. In vitro antioxidant potential of selected aphrodisiac medicinal plants. J. Biol. Regul. Homeost. Agents 31(2): 419-424.

Sarina, Y., Nakano, O., Hashimoto, T., Kimura, K., Asakawa, Y., Zhong, M., Narimatsu, S. \& Gohda, E. 2013. Induction of neurite outgrowth in PC12 cells by artemisinin through activation of ERK and p38 MAPK signaling pathways. Brain Res. 1490: 61-71.

Suzuki, N., Numakawa, T., Chou, J., de Vega, S., Mizuniwa, C., Sekimoto, K., Adachi, N., Kunugi, H., Arikawa-Hirasawa, E., Yamada, Y. \& Akazawa, C. 2014. Teneurin-4 promotes cellular protrusion formation and neurite outgrowth through focal adhesion kinase signaling. FASEB J.28(3): 1386-1397.

Suzuki, N., Fukushi, M., Kosaki, K., Doyle, A.D., de Vega, S., Yoshizaki, K., Akazawa, C., Arikawa-Hirasawa, E. \& Yamada, Y. 2012. Teneurin-4 is a novel regulator of oligodendrocyte differentiation and myelination of smalldiameter axons in the CNS. J. Neurosci.32(34): 11586-11599.

Wang, Y.P., Wang, Z.F., Zhang, Y.C., Tian, Q. \& Wang, J.Z. 2004. Effect of amyloid peptides on serum withdrawal-induced cell differentiation and cell viability. Cell Res. 14(6): 467-472.
Zhang, Z., Cai, L., Zhou, X., Su, C., Xiao, F., Gao, Q. \& Luo, H. 2015. Methyl 3,4-dihydroxybenzoate promote rat cortical neurons survival and neurite outgrowth through the adenosine A2a receptor/PI3K/Akt signaling pathway. Neuroreport 26(6): 367-373

Sutin Wansawat \& Tewin Tencomnao*

Clinical Biochemistry and Molecular Medicine

Department of Clinical Chemistry

Faculty of Allied Health Sciences

Chulalongkorn University

10330 Bangkok

Thailand

Mani Iyer Prasanth \& Tewin Tencomnao*

Age-related Inflammation and Degeneration Research Unit Department of Clinical Chemistry

Faculty of Allied Health Sciences

Chulalongkorn University

10330 Bangkok

Thailand

Ciro Isidoro

Laboratory of Molecular Pathology

Department of Health Sciences

Università del Piemonte Orientale 'A. Avogadro', Novara Italy

*Corresponding author; email: tewin.t@chula.ac.th

Received: 30 May 2018

Accepted: 18 September 2018 